\title{
Characterization of Initial Events in Bacterial Surface Colonization by Two Pseudomonas Species Using Image Analysis
}

\author{
Robert F. Mueller, ${ }^{1}$ William G. Characklis, ${ }^{2, *}$ Warren L. Jones, ${ }^{3}$ and \\ John T. Sears ${ }^{4}$ \\ Departments of ${ }^{1,2,3}$ Civil and Agricultural Engineering, and ${ }^{2,4}$ Chemical \\ Engineering, Center for Interfacial Microbial Process Engineering, Montana \\ State University, Bozeman, MT 59717
}

Received September 5, 1991/Accepted December 13, 1991

\begin{abstract}
The processes leading to bacterial colonization on solidwater interfaces are adsorption, desorption, growth, and erosion. These processes have been measured individually in situ in a flowing system in real time using image analysis. Four different substrata (copper, silicon, 316 stainless-steel and glass) and 2 different bacterial species (Pseudomonas aeruginosa and Pseudomonas fiuorescens) were used in the experiments. The flow was laminar $(R e=1.4)$ and the shear stress was kept constant during all experiments at $0.75 \mathrm{~N} \mathrm{~m}^{-2}$. The surface roughness varied among the substrata from $0.002 \mu \mathrm{m}$ (for silicon) to $0.015 \mu \mathrm{m}$ (for copper). Surface free energies varied from 25.1 dynes $\mathrm{cm}^{-1}$ for silicon to 31.2 dynes $\mathrm{cm}^{-1}$ for copper. Cell curface hydrophobicity, reported as hydrocarbon partitioning values, ranged from 0.67 for Ps. fluorescens to 0.97 for Ps. aeruginosa.

The adsorption rate coefficient varied by as much as a factor of 10 among the combinations of bacterial strain and substratum material, and was positively correlated with surface free energy, the surface roughness of the substratum, and the hydrophobicity of the cells. The probability of desorption decreased with increasing surface free energy and surface roughness of the substratum. Cell growth was inhibited on copper, but replication of cells overlying an initial cell layer was observed with increased exposure time to the cell-containing bulk water. A mathematical model describing cell accumulation on a substratum is presented.

Key words: bacterial colonization - kinetic rates - solidwater interfaces - Pseudomonas aeruginosa $\cdot$ Pseudomonas fluorescens $\cdot$ image analysis
\end{abstract}

\section{INTRODUCTION}

A requisite event in biofilm accumulation is the adsorption of bacteria cells at a substratum. If these adsorbed cells find suitable environmental conditions, biofilm formation will occur through continued adsorption and growth of adsorbed cells. The thickness of the biofilm can vary from a single cell layer to several hundred millimeters as found in algal mats. Biofilms can be deleterious when they induce corrosion, increase the heat transfer resistance in heat exchangers, increase fluid frictional resistance in pipes, increase the drag of a ship, or influence the hygienic safety of municipal water supplies and processed food. ${ }^{8}$ On the other hand, biofilms

\footnotetext{
* To whom all correspondence should be addressed.
}

can be beneficial, as illustrated by the immobilization of microorganisms for waste water treatment and metal leaching in biohydrometallurgy.

Cellular accumulation at an interface is the net result of several rate processes, including adsorption, desorption, growth, and erosion. ${ }^{10}$ Thus, measuring only the net accumulation of cells does not provide sufficient information to control, predict, or simulate a specific system. Measurement of the respective rate coefficients for each of these processes is necessary for fundamental characterization and simulation of the colonization events at solid-liquid interfaces. Simulation models can then be used to predict cell accumulation on different substrata under various environmental conditions. Models for initial colonization could be combined with existing models for mature biofilms, ${ }^{33}$ so that the accumulation and activity of a biofilm could be predicted and simulated.

The goal of the reported experiments was to characterize early bacterial colonization in a laminar flow system as influenced by various solid-water interfaces and microbial species. The study had the following objectives:

1. Determine the rate coefficients for early bacterial colonization of Pseudomonas aeruginosa on copper, silicon, 316 stainless-steel, and glass.

2. Compare the rate of colonization of 2 motile bacterial species commonly found in pipeline environments. $P s$. aeruginosa isolated from a pipeline environment and Pseudomonas fluorescens strain CC-840406-E were previously studied $d^{4,10,11,17,22,29}$ and also used here.

3. Perform simulations of early surface colonization on solid interfaces at various nutrient conditions for single and mixed populations.

\section{Previous Research}

Cellular accumulation at the substratum could be influenced by hydrodynamics, water chemistry, the microorganisms in the system and their physiological state, 
and interfacial properties. Temperature, $\mathrm{pH}$, substrate concentration in the bulk liquid, the presence of trace elements and other nutrients such as phosphate and nitrogen and their ratio to carbon, the ionic strength of the bulk liquid, the coating of the surface, the substratum material, the substratum surface free energy (as reflected by hydrophobicity and surface roughness), as well as cellular properties may influence the rate processes leading to bacterial accumulation on a solid-liquid interface ${ }^{1,12,19,20,30}$.

Most literature on bacterial colonization on solidliquid interfaces emphasizes various microbial, chemical, biochemical, and physico-chemical variables, but does not differentiate between adsorption, desorption, or growth on surfaces. A few reports can be found describing hydrodynamic influences on bacterial colonization. Powell and Slater ${ }^{21}$ and Escher and Characklis ${ }^{10}$ used image analysis to study the kinetics of cellular colonization in laminar flow on a smooth glass substratum. Powell and Slater used Bacillus cereus, and compared their experimental results with theoretically calculated deposition rates for nonmotile cells using a model proposed by Bowen and co-workers ${ }^{6}$ for adsorption of latex particles. Escher and Characklis ${ }^{10}$ distinguished between adsorption, desorption, growth, and erosion of Ps. aeruginosa to describe and then simulate cell accumulation. They used Bowen's model to calculate cellular transport rate to the solid-water interface, sticking efficiency, and particle capture factor from experimental data. Fluid shear stress and bulk water cell concentration were varied, and the rates of cellular colonization determined. Escher and Characklis suggested that sorption-related kinetics should be treated as first order with respect to cell concentration in the bulk water and zero-order with respect to cell surface concentration. Growth-related kinetics were treated as first order with respect to cellsurface concentration. They observed an exponentially decreasing cell accumulation rate with increasing shear stress at the solid-water interface.

\section{Process Analysis at the Solid-Liquid Interface}

The processes occurring during early colonization at the solid-liquid interface can be summarized as follows ${ }^{10,11,15}$ :

- Conditioning of the substratum by organic molecules.

- Transport of cells from the bulk water to the solidliquid interface.

- Adsorption of cells on the substratum.

- Transformation of reversibly adsorbed cells to irreversibly adsorbed cells.

- Desorption of reversibly adsorbed cells from the substratum into the bulk water.

- Growth of irreversibly adsorbed cells.

- Erosion of cells from adsorbed colonies into the bulk water.
The initial events in biofilm accumulation are substratum conditioning by adsorption of organic molecules followed by adsorption of cells; adsorption is defined as the linking of a colony-forming unit (CFU) with the substratum. A CFU consists of one or more aggregated cells which form a single colony on the substratum. Some of these adsorbed cells remain on the surface (irreversibly adsorbed cells), while others may desorb after some time (reversibly adsorbed cells); desorption is defined as the breaking of the linkage of a CFU and its complete removal from the substratum.

Irreversibly adsorbed cells will grow under suitable environmental conditions; growth is defined as an increase in the number of microbial cells or an increase in microbial mass. ${ }^{7}$ Here, the increase in cell number was used to obtain growth rates. Cells in a colony were termed "separated" when the spatial distance between the 2 separating cells exceeded $0.1 \mu \mathrm{m}$. The daughter cells may either erode (reduce the number of cells within the $\mathrm{CFU}$ ) or also become irreversibly adsorbed.

\section{Rate Expressions}

The observed accumulation rate of cells on a substratum is the net result of adsorption rate, desorption rate, growth rate, and erosion rate. By measuring the individual rates in situ by image analysis methods, the rate coefficients for the various processes can be determined using the following rate expressions for adsorption, desorption, growth, and erosion at the interface. ${ }^{10}$

$$
\begin{gathered}
r_{a}=K_{a} X_{b}^{\prime} \\
r_{g}=\mu_{s} X^{\prime \prime} \\
r_{e}=K_{e} X^{\prime \prime} \\
r_{d}=(1-\alpha) K_{a} X_{b}^{\prime} \\
K_{\mathrm{irr}}=\alpha K_{a}
\end{gathered}
$$

where

$X_{b}^{\prime}: \quad$ cell concentration in the bulk water [cell\# $\mathrm{L}^{-3}$ ];

$X^{\prime \prime}: \quad \quad \quad$ cell surface concentration [cell\# $\mathrm{L}^{-2}$ ];

$r_{a}, r_{d}, r_{g}, r_{e}:$ rate of adsorption, desorption, growth, or erosion, respectively [cell\# $\mathrm{L}^{-2} t^{-1}$;

$K_{a}: \quad$ specific rate coefficient for adsorption [ $\left.\mathrm{L} t^{-1}\right]$

$K_{\text {irr }}: \quad$ specific rate coefficient of irreversible adsorption $\left[\mathrm{L} t^{-1}\right]$;

$\mu_{s}: \quad$ specific growth rate on the substratum

$\left[t^{-1}\right]$

$K_{e}: \quad$ specific erosion rate on the substratum

$\left[t^{-1}\right]$

$\alpha: \quad$ probability of irreversible adsorption $[-]$; and

$(1-\alpha):$ probability of desorption $[-]$.

The influence of substrate concentration on cellular growth is best described by the Monod equation, since 
the dependence of growth rates of organisms on substrate concentration are assumed to be the same in the biofilm and in the planktonic state ${ }^{4}$ :

$$
\mu=\mu_{\max } S /\left(K_{s}+S\right)
$$

where

$\mu_{\max }:$ maximum specific growth rate $\left[t^{-1}\right]$,

$K_{s}: \quad$ half saturation coefficient $\left[M \mathrm{~L}^{-3}\right]$, and

$S: \quad$ substrate concentration $\left[M \mathrm{~L}^{-3}\right]$.

The coefficients $K_{s}$ and $\mu_{\max }$ have been determined to be $2.0 \mathrm{~g} \mathrm{~m}^{-3}$ and $0.40 \mathrm{~h}^{-1}$, respectively, for Ps. aeruginosa grown on glucose. ${ }^{22}$ When the maximum specific growth rate on a surface is known, equation (6) can be used to calculate the specific growth rate at various bulk water substrate concentrations. The rate of cell accumulation on a substratum can then be expressed with the rate coefficients for irreversible adsorption, growth, and erosion:

$$
d X^{\prime \prime} / d t=K_{\mathrm{irr}} X_{b}^{\prime}+\mu_{s} X^{\prime \prime}-K_{e} X^{\prime \prime}
$$

Equation (7) does not have individual terms for death and decay of the adsorbed cells. These rates are included in growth and erosion. Equation (7) was used to describe early surface colonization in this study.

\section{MATERIALS AND METHODS}

\section{Experimental System}

The experimental system consisted of three major components: (1) a chemostat; (2) a flow cell; and (3) a microscope equipped with an image analysis system (Fig. 1). Bacterial cells were grown on glucose in a chemostat (330-mL volume) at a dilution rate of $0.2 \mathrm{~h}^{-1}$ until steady state conditions were reached. Growth in the chemostat was carbon limited $\left(40 \mathrm{~g} \mathrm{~m}^{-3}\right.$ as total organic carbon, TOC; $\mathrm{C}: \mathrm{N}$ ratio less than 5 ) and the $\mathrm{pH}$ was phosphatebuffered at $\mathrm{pH}$ 6.8. Micronutrients were added according to Trulear et al. ${ }^{29}$ The chemostat effluent cell

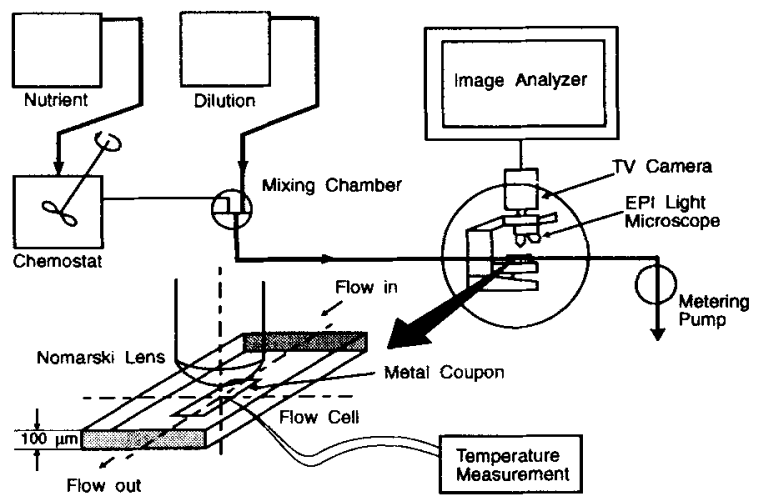

Figure 1. Experimental system. The chemostat was fed by a nutrient solution, the effluent was mixed with dilution water in a mixing chamber and the mixture was pumped through a flow cell. Coupons embedded at the bottom of the flow cell were monitored continuously by a microscope interfaced to an image analyzer. concentration varied from $3.8 \times 10^{7}$ to $4.5 \times 10^{7}$ cells $\mathrm{mL}^{-1}$ (measured as total count). The chemostat effluent organic carbon content varied between 3.2 and $5.0 \mathrm{~g} \mathrm{~m}^{-3}$ (measured as dissolved organic carbon, DOC). The chemostat effluent was diluted by a factor of approximately 10 with carbon-free and cell-free dilution water before entering the flow cell in which colonization was observed. The dilution water had the same chemical composition as the chemostat feed except that no organic carbon was added. Hence, influent to the flow cell contained DOC between 0.1 and $0.6 \mathrm{~g} \mathrm{~m}^{-3}$ and cell concentration between $10^{6}$ and $10^{7}$ cells $\mathrm{mL}^{-1}$. Temperature was controlled in the chemostat at $30^{\circ} \mathrm{C}$, and the temperature at the solid-water interface (in the flow cell) was measured at $22 \pm 1^{\circ} \mathrm{C}$. Microscopic light did not increase the substratum temperature significantly during $300 \mathrm{~min}$ utes exposure with a bulk water flow of $0.12 \mathrm{~L} \mathrm{~h}^{-1}$. All experiments were conducted in laminar flow $(R e=1.4)$ at a constant shear stress of $0.75 \mathrm{~N} \mathrm{~m}^{-2}$.

The diluted bacterial cell suspension was pumped by a nonpulsing gear pump at a constant flow rate through a flow cell (Table I). A coupon was embedded in the bottom of the flow cell and served as the substratum. Reflective substrata (copper, silicon, 316 stainless-steel) were monitored continuously using EPI-reflective light from a microscope equipped with a Nomarski lens. Transmitted light was used for monitoring the transparent surface (e.g., glass). Magnification was 1000 to $1500 \times$. At lower magnification, the light reflection from the surface was too dispersed to obtain quantitative information on cell colonization. The microscope output was linked to a video camera. The video signal was transferred to an image analysis system which converted the grey image from the video camera into a binary image.

The metal coupons were mechanically polished with "Buehler Alpha Micropolish II deagglomerated Alumina 1.0 and 0.3 " in distilled water to produce a sufficiently polished surface for observation of individual bacterial cells. The polish has a hexagonal crystal structure and a particle size of 1.0 and $0.3 \mu \mathrm{m}$, respectively.

Ps. aeruginosa isolated from a pipeline environment and Ps. fluorescens strain CC-840406-E were the test organisms. Both Pseudomonas strains are aerobic, rodshaped, polar flagellated, gram-negative cells, generally 1.0 to $2.5 \mu \mathrm{m}$ long and 0.4 to $0.6 \mu \mathrm{m}$ in diameter. ${ }^{7}$ The

Table I. System-specific parameters of the flow cell used in the experiments.

\begin{tabular}{lc}
\hline Length of flow cell & $40.00 \mathrm{~mm}$ \\
Length of metal coupon & $26.50 \mathrm{~mm}$ \\
Width of flow cell & $12.10 \mathrm{~mm}$ \\
Width of metal coupon & $6.70 \mathrm{~mm}$ \\
Height of flow channel & $0.10 \mathrm{~mm}$ \\
Cross sectional area of flow channel & $1.21 \mathrm{~mm}^{2}$ \\
Bulk liquid flow rate & $0.12 \mathrm{~L} \mathrm{~h}^{-1}$ \\
Bulk liquid mean velocity & $0.03 \mathrm{~m} \mathrm{~s}^{-1}$ \\
Shear stress at the solid--water interface & $0.75 \mathrm{~N} \mathrm{~m}^{-2}$ \\
\hline
\end{tabular}


average cell volume was determined by image analysis for $P_{S}$. aeruginosa and $P$ s. fluorescens to be $V_{c}=$ $0.675 \pm 0.105 \mu \mathrm{m}^{3}$ at $\mu=0.2 \mathrm{~h}^{-1}$. $V_{c}$ was determined from 4 identical chemostat runs $\left(D=0.2 \mathrm{~h}^{-1}\right)$, with a total number of cells measured larger than 200. There was no significant difference between the maximum specific growth rate of $P$ s. aeruginosa and $P$ s. fluorescens in batch cultures $\left(\mu_{\max }=0.45 \mathrm{~h}^{-1}\right) .^{17}$

\section{Analytical Methods}

Total Cell Count. The water samples (bulk water and chemostat effluent) were fixed in $2 \%$ formalin solution and stored at $4{ }^{\circ} \mathrm{C}$. All containers were autoclaved prior to sampling. The prepared sample was homogenized and suspended in $2 \mathrm{~mL}$ acridine orange $(0.01 \%)$ for 60 minutes. The stained sample was filtered through a $0.2-\mu \mathrm{m}$ black filter, and cells were counted by image analysis using fluorescent light at $1000 \times$ magnification. $^{13}$ Ten fields on each filter were averaged to determine the cell concentration in the sample. Replicates of several filters with the same sample yielded a standard deviation of less than $10 \%$.

Viable Cell Counts. Serial $10 \times$ dilutions (phosphate buffer) of chemostat and bulk water samples were spread in triplicate on R2A-agar. Replicates of several plates of the same sample resulted in a standard deviation of less than $15 \%$ for viable cell counts.

Cell Surface Hydrophobicity. The BATH-test method, developed by Rosenberg and co-workers, ${ }^{25,26}$ was adapted for use with image analysis. Equal volumes of $n$-octane or $n$-hexadecane were added to a suspension of known cell concentration in aqueous solution. Cell surface hydrophobicity is reported as the fraction of cells removed by hexadecane or octane, respectively, and is called hexadecane or octane partitioning value, respectively. $p$-Xylene was abandoned as an extracting fluid because it produced unreliable results. Other researchers have also reported problems with the use of $p$-xylene for measuring cell surface hydrophobicity. ${ }^{31}$

Organic Carbon. TOC was measured using a Dohrman Model DC 80 total organic carbon analyzer. Dissolved organic carbon was determined by filtering a sample through a PTFE membrane with a pore size of $0.2 \mu \mathrm{m}$, that had been rinsed 8 to 10 times with dilute phosphoric acid.

Surface Roughness. Surface roughness was determined from a reflected light scatter distribution using a Rayleigh perturbation relationship. A reflector power spectral density (PSD) function can be calculated from the light scatter at various reflection angles. In general, the calculated PSD behaves as a function of the surface topography, but is relatively unaffected by large isolated scratches. Integrating the PSD function gives the root mean square (RMS) surface roughness value. ${ }^{28}$

Surface Free Energy (SFE). Contact angle analyses were performed on samples of the 316 stainless-steel, silicon, copper, and glass. Critical surface tension $\left(\gamma_{c}\right)$ was determined in accordance with the methods of Zisman, ${ }^{35}$ as modified by Baier and Meyer. ${ }^{3}$ The method developed by Kaelble ${ }^{14}$ was used to determine polar $\left(\gamma_{p}\right)$ and dispersive $\left(\gamma_{d}\right)$ components of the composite surface free energy (SFE) $\left(\gamma_{s}\right)$. All samples used for analysis, as well as for the colonization experiments, were washed with deionized water, acetone, $70 \%$ ethanol, and deionized water. No further sample preparation or cleaning was performed prior to surface tension/contact angle measurements.

The cosine of the contact angle $(\theta)$ of the solid interface to water (surface hydrophobicity) is directly proportional to the surface roughness. ${ }^{2,5}$ Thus, a rough surface tends to exaggerate the wetting behavior of a solid. When the contact angle of a smooth surface is small, it is even smaller on a rough surface of identical material.

Temperature at the Solid-Liquid Interface. Two thermocouples (copper/constantane) were flush-mounted on a 316 stainless-steel substratum to measure effects of the focused microscopic light on substratum surface temperature. One thermocouple tip was placed at the point of light focus, whereas the other thermocouple was placed at a $10-\mathrm{mm}$ horizontal distance from the light focus. The flow cell was operated in the same manner as for the accumulation experiments, and temperature was monitored continuously.

Image Analysis. A Cambridge Q10, equipped with an image analyzer unit (68000 processor), was used in the experimental system. In addition to the display and output of the measurements, the image analyzer performed limited statistical analysis. Images were taken at 10 -minute intervals, and manipulated by a digipad connected to the image analyzer. Image analysis counted the actual number of cells on the surface and size and location for each colony. The data were stored to disk during experiments and later retrieved for statistical analysis.

Rate of Adsorption and Desorption. The rates of adsorption and desorption were measured by exposing the solid interface to a bulk water flow of constant cell concentration and shear stress $\left(0.75 \mathrm{~N} \mathrm{~m}^{-2}\right)$. Individual cells were counted and their location and size on the substratum stored over time. A linear regression of the number of cells adsorbing or desorbing versus time yielded estimates for adsorption and desorption rate. The probability of desorption was calculated as the ratio of desorption to total initial adsorption.

\section{Rate of Growth and Erosion}

The substrata were exposed to a bulk water flow of approximately $3 \times 10^{6}$ cells $\mathrm{mL}^{-1}$ until the cell surface density was between 2000 and $3000 \mathrm{CFU} \mathrm{mm}^{-2}$. After this initial colonization period, the bulk water flow was switched from diluted chemostat effluent to a sterile solution identical to the chemostat feed. The rate of growth on surfaces was determined by following the replication of individual cells over time. Simultaneously, the rate of erosion could be determined by observing individual 
cells eroding from immobilized colonies. Hence, specific growth rate, doubling time, and specific rate of erosion could be determined by regression analysis.

\section{RESULTS}

Results were obtained for 4 different materials and 2 different bacterial strains. Substrata included copper, 316 stainless-steel, silicon, and glass. The bacterial strains tested were PS. aeruginosa and Ps. fluorescens.

\section{Surface Colonization by Ps. aeruginosa}

Ps. aeruginosa cells were transported to the interface and colonized either as single cells or in a divided cell state. Aggregation was not observed on the substratum, and desorption occurred as single or divided cells from the substratum to the bulk water. Rate coefficients for Ps. aeruginosa on various metal substrata are summarized in Table II.

\section{Copper}

Oxidation of copper results in the formation of a copper oxide layer within hours of exposure to air. The copper oxide layer has a protective function for the metal underneath and can be easily detected by visual observation. A freshly polished copper surface is shiny and reflective, whereas an oxidized copper surface looks dull and absorbs light. Copper, a soft metal, polished very quickly, but was difficult to keep clean. The orientation of polishing was determined from a light scatter surface roughness measurement. ${ }^{28}$ The RMS surface roughness of a freshly polished copper coupons was $0.015 \mu \mathrm{m}$. After exposure to air for several weeks, the RMS surface roughness increased to $0.17 \mu \mathrm{m}$. Cell accumulation on the copper substratum was expressed as cell surface concentration $\left(X^{\prime \prime}\right)$ and observed for a bulk water cell concentration of $1.50 \times 10^{6}$ cells $\mathrm{mL}^{-1}$ (Fig. $2 \mathrm{a}$ ). The steep slope indicates a high rate of adsorption $\left(K_{a}=\right.$ $2.23 \mathrm{~mm} \mathrm{~h}^{-1}$ ), whereas the rate of desorption was rather low (probability of desorption $(1-\alpha)=0.10)$. During initial colonization, there was no replication of cells observed when using copper as substratum (Fig. 2b). Even for an extended period of time ( 24 hours), no replication was observed. However, if the exposure to a cell suspension was long enough for a monolayer of cells to accumulate, replication of cells in the second and higher cell layers was observed (data not reported).

\section{Silicon}

Silicon is used in industry as a semiconductor material mostly in its monocrystalline form. To allow very accurate photographic etching procedures, silicon chips are thinly sliced and polished with high precision to very low surface roughness values and a high degree of flatness. The monocrystalline silicon substratum had a RMS surface roughness of $0.002 \mu \mathrm{m}$.

The bulk water cell concentration was $3.5 \times 10^{6}$ cells $\mathrm{mL}^{-1}$ during the accumulation experiment (Fig. 3a). The adsorption coefficient was low $\left(K_{a}=0.47 \mathrm{~mm} \mathrm{~h}^{-1}\right)$ and the probability of desorption was high $[(1-\alpha)=$ $0.86]$; most cells did not remain on the surface for an extended period of time after initial adsorption. The rate of erosion $\left(K_{e}=0.32 \mathrm{~h}^{-1}\right)$ was slightly higher than the specific growth rate $\left(\mu_{s}=0.28 \mathrm{~h}^{-1}\right)$ (Fig. 3b). Replication of adsorbed cells often resulted in desorption of both mother and daughter cells. Hence, the accumulation of cells on the silicon surface was slow. Even cells that were absorbed for a long period of time (over 200 minutes) desorbed when shear was increased.

\section{Stainless-Steel}

A freshly polished 316 stainless-steel surface had a RMS surface roughness of $0.008 \mu \mathrm{m}$. After this surface was exposed to air for several weeks, the RMS surface roughness increased to $0.012 \mu \mathrm{m}$.

The bulk water cell concentration during the accumulation experiment was $1.1 \times 10^{6}$ cells $\mathrm{mL}^{-1}$ (Fig. $4 \mathrm{a}$ ). The coefficient of adsorption was $K_{a}=1.82 \mathrm{~mm} \mathrm{~h}^{-1}$, the probability of desorption was $(1-\alpha)=0.30$, and the specific growth rate on the substratum $\left(\mu_{s}=0.33 \mathrm{~h}^{-1}\right)$ was much higher than the rate of erosion $\left(K_{e}=0.09 \mathrm{~h}^{-1}\right)$ (Fig. 4b).

\section{Surface Characterization of the Substratum}

Substratum RMS surface roughness and SFE were measured for all metal surfaces used in the experiments, and were correlated to the adsorption coefficient of PS.

Table II. Summary of experimental results for Pseudomonas aeruginosa.

\begin{tabular}{llllll}
\hline Coefficients & \multicolumn{1}{c}{ Units } & Copper & 316 Stainless & \multicolumn{1}{c}{ Silicon } & \multicolumn{1}{c}{ Glass } \\
\hline Total SFE & {$\left[\right.$ dynes cm $\left.{ }^{-1}\right]$} & 31.2 & 26.9 & 25.1 & 27.9 \\
Polar SFE & {$[\%$ of tot. SFE] } & 11 & 7 & 13 & 30 \\
RMS roughn. & {$[\mu \mathrm{m}]$} & 0.015 & 0.008 & 0.002 & $\mathrm{ND}^{\mathrm{a}}$ \\
$K_{a}$ & {$\left[\mathrm{~mm} \mathrm{~h}^{-1}\right]$} & $2.22 \pm 0.43$ & $1.84 \pm 0.22$ & $0.47 \pm 0.04$ & $1.14^{11}$ \\
$(1-\alpha)$ & {$[-]$} & $0.21 \pm 0.02$ & $0.30 \pm 0.02$ & $0.86 \pm 0.06$ & $0.62 \pm 0.18^{11}$ \\
$K_{\text {irr }}$ & {$\left[\mathrm{mm} \mathrm{h}^{-1}\right]$} & $1.75 \pm 0.41$ & $1.29 \pm 0.20$ & $0.07 \pm 0.02$ & $0.43 \pm 0.20$ \\
$K_{e}$ & {$\left[\mathrm{~h}^{-1}\right]$} & 0.0 & $0.09 \pm 0.01$ & $0.32 \pm 0.01$ & $0.32 \pm 0.08^{11}$ \\
$\mu_{s}$ & {$\left[\mathrm{~h}^{-1}\right]$} & 0.0 & $0.33 \pm 0.06$ & $0.28 \pm 0.08$ & $0.51 \pm 0.11^{11}$ \\
\hline
\end{tabular}

\footnotetext{
${ }^{\mathrm{a}}$ Not determined.
} 

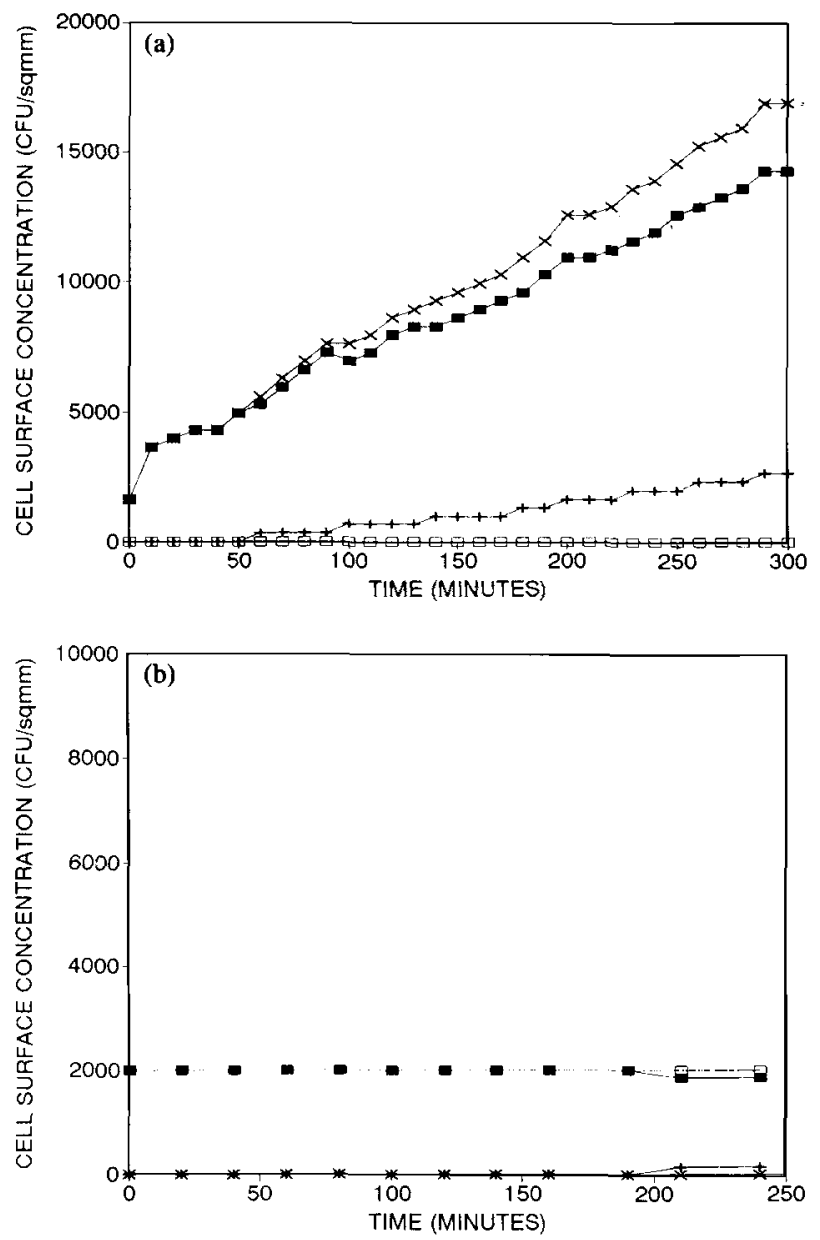

Figure 2. Progression of cell accumulation of Pseudomonas aeruginosa on copper at a bulk water cell concentration of $1.4 \times 10^{6}$ cells $\mathrm{mL}^{-1}$. (a) Accumulation ( $\boldsymbol{(}$ ) is displayed as net result of adsorption $(\times)$, desorption/erosion $(+)$, and growth $(\square)$. (b) A sterile nutrient $(40 \mathrm{ppm} \mathrm{C})$ was used when cell concentration of $2000 \mathrm{CFU} \mathrm{mm^{-2 }}$ was reached to determine maximum specific growth rate and erosion rate. Shear stress was $0.75 \mathrm{~N} \mathrm{~m}^{-2}$.

aeruginosa (Table II). Cellular adsorption increased with increasing roughness of the substratum, and the probability of desorption decreased with increasing surface roughness. Hence, the rate of irreversible adsorption was strongly influenced by the substratum roughness.

Roughness measurements for glass could not be determined due to the refraction of light within the sample. The low values for total and polar SFE may be indicative of contamination of the surfaces by organic material remaining on the surface following colonization experiments. However, no controls were tested; therefore, this hypothesis cannot be confirmed. Increasing RMS surface roughness was reflected by a linear increase in total SFE $\left(r^{2}=0.97\right)$.

\section{Surface Colonization by Ps. fluorescens}

The cellular colonization pattern of Ps. fluorescens was different from the behavior of Ps. aeruginosa. Ps. fluorescens cells were transported as single cells to the
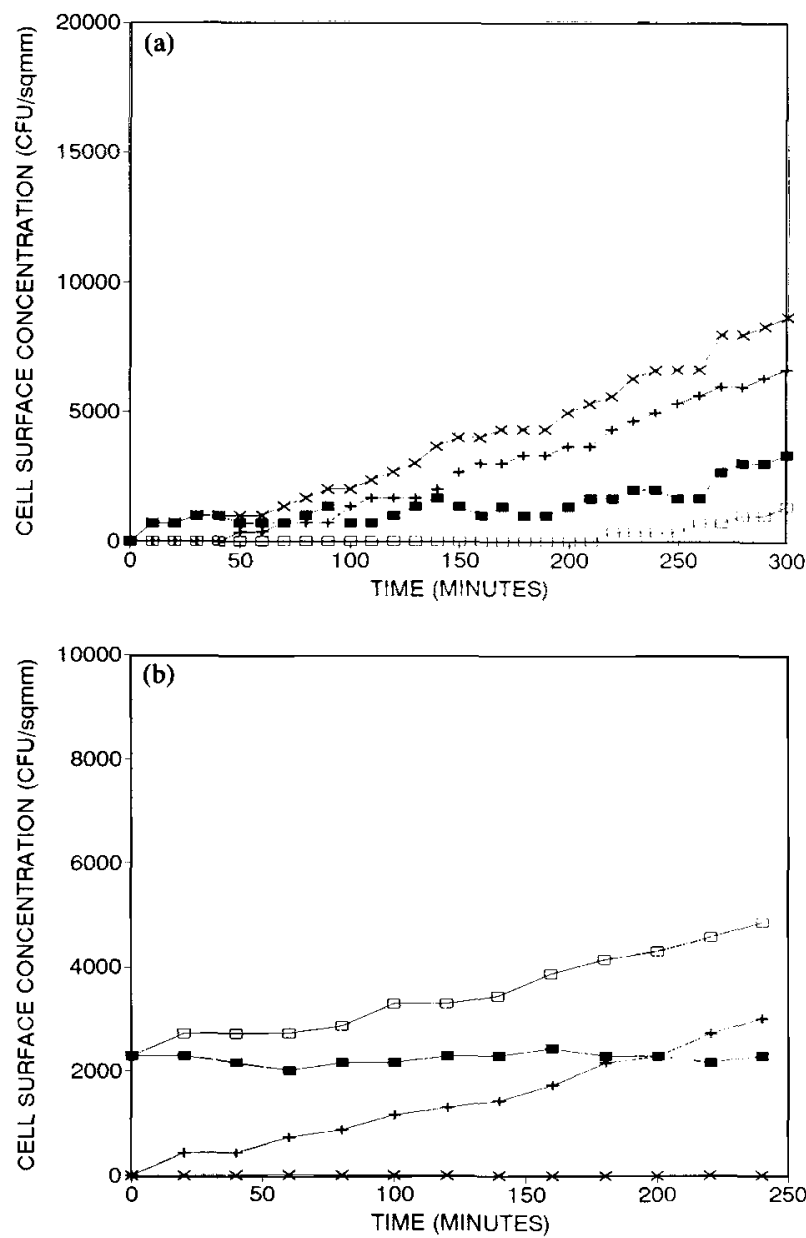

Figure 3. Progression of cell accumulation of Ps. aeruginosa on silicon at a bulk water cell concentration of $3.5 \times 10^{6}$ cells $\mathrm{mL}^{-1}$. (a) Accumulation (a) is displayed as net result of adsorption $(X)$, desorption/erosion (+), and growth ( $\square$ ). (b) A sterile nutrient $(40 \mathrm{ppm} \mathrm{C})$ was used when cell concentration of $2100 \mathrm{CFU} \mathrm{mm}$ was reached to determine maximum specific growth rate and erosion rate. Shear stress was $0.75 \mathrm{~N} \mathrm{~m}^{-2}$.

substratum, but adsorption occurred more often in aggregates. Desorption of cells, even from aggregates, occurred as single cells in most cases. Growth rate and the rate of erosion were not determined for Ps. fluorescens. Experimental results for adsorption and desorption of Ps. fluorescens on stainless-steel and glass are summarized and compared with those for Ps. aeruginosa in Table III.

\section{Stainless-Steel}

Accumulation of Ps. fluorescens on 316 stainless-steel was observed at a cell concentration of $1.3 \times 10^{6}$ cells $\mathrm{mL}^{-1}$. Ps. fluorescens on stainless-steel had an adsorption rate coefficient of $K_{a}=0.30 \mathrm{~mm} \mathrm{~h}^{-1}$ and a probability of desorption $(1-\alpha)=0.61$.

\section{Glass}

Cell accumulation of Ps. fluorescens on glass was observed at a bulk water cell concentration of $3.85 \times 10^{6}$ 

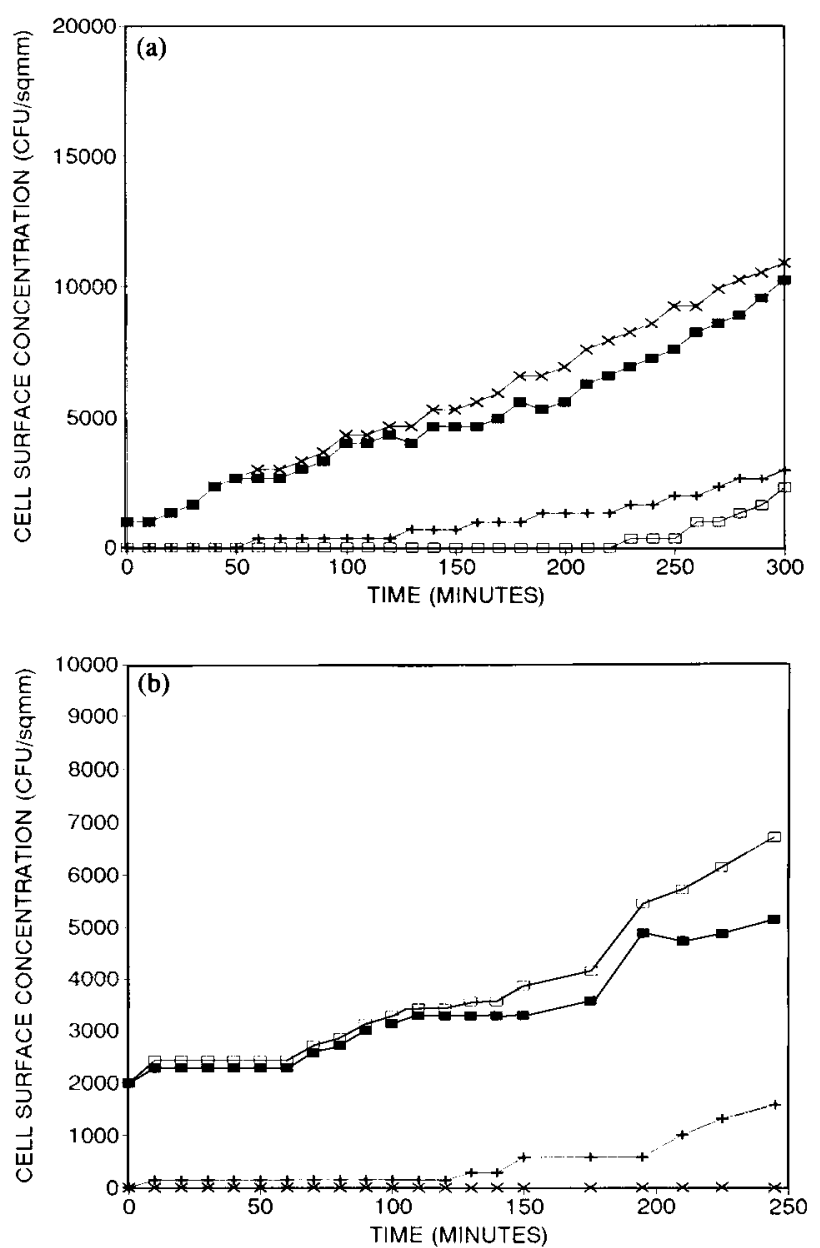

Figure 4. Progression of cell accumulation of Ps. aeruginosa on 316 stainless-steel at a bulk water cell concentration of $1.1 \times 10^{6}$ cells $\mathrm{mL}^{-1}$. (a) Accumulation ( $\mathbf{\square}$ ) is displayed as net result of adsorption $(\times)$, desorption/erosion $(+)$, and growth $(\square)$. (b) A sterile nutrient (40 ppm C) was used when cell concentration of $2000 \mathrm{CFU} \mathrm{\textrm {mm } ^ { - 2 }}$ was reached to determine maximum specific growth rate and erosion rate. Shear stress was $0.75 \mathrm{~N} \mathrm{~m}^{-2}$.

cells $\mathrm{mL}^{-1}$. The adsorption rate coefficient on glass was $K_{a}=0.25 \mathrm{~mm} \mathrm{~h}^{-1}$, the probability of desorption was $(1-\alpha)=0.41$.

\section{Cell Surface Hydrophobicity}

The hexadecane partitioning values for both species were higher than the octane partitioning values (Table III). Mean hydrocarbon partitioning values were calculated by averaging the hexadecane and octane partitioning values. These partitioning values were found to be statistically significantly lower for Ps. fluorescens than for Ps. aeruginosa.

\section{DISCUSSION}

\section{Colonization by Ps. aeruginosa}

Adsorption rate and desorption rate were assumed to be independent of the accumulated cell surface concentration and treated as first order with respect to bulk water cell concentration; the rate of erosion and replication were assumed to be independent of the bulk water cell concentration and first order with respect to the cell surface concentration. These assumptions are based on theoretical considerations (e.g., cellular reproduction is an autocatalytic process) as well as on experimental results. ${ }^{10}$

Reversible and irreversible adsorption coefficients of Ps. aeruginosa were dependent on the substratum and its surface characteristics as reflected by SFE and roughness (Table II, Fig. 5). The lowest rate of adsorption was found on the very smooth monocrystalline silicon. The silicon substratum had the lowest RMS surface roughness and the lowest SFE value of all tested substrata $\left(0.07 \mathrm{~mm} \mathrm{~h}^{-1}, 0.002 \mu \mathrm{m}\right.$, and 25.1 dynes $\mathrm{cm}^{-1}$, respectively). Only $14 \%$ of all initially adsorbed cells became irreversibly adsorbed. The rate of irreversible adsorption on 316 stainless-steel was 20 times higher than on silicon with $70 \%$ of all initially adsorbed cells becoming irreversibly adsorbed over time. Copper represented the highest substratum SFE with the roughest surface resulting in a $23 \times$ higher rate of irreversible adsorption than on silicon and 79\% of the initially adsorbed cells becoming irreversibly adsorbed. Generally, the rate of adsorption on a substratum increased with increasing SFE and surface roughness of the substratum. Because SFE data reflect both the composition of the material and the surface roughness, these two variables cannot be treated separately. To distinguish between the effects of the two on colonization behavior, identical materials of various surface roughnesses must be tested.

Dislocations on the polished surfaces approximately $\leq 0.1 \mu \mathrm{m}$ did not influence the rate of adsorption as determined by visual observation. The general surface

Table III. Summary of experimental results for Pseudomonas fluorescens and Pseudomonas aeruginosa.

\begin{tabular}{lllr}
\hline \multicolumn{1}{c}{ Coefficients } & Units & Ps. aeruginosa & Ps. fluorescens \\
\hline Hexadecane part. value & {$[-]$} & $0.99 \pm 0.01$ & $0.80 \pm 0.04$ \\
Octane part. value & {$[-]$} & $0.95 \pm 0.01$ & $0.54 \pm 0.11$ \\
Mean-HC part. value & {$[-]$} & $0.97 \pm 0.02$ & $0.67 \pm 0.13$ \\
$K_{a}$ (glass) & {$\left[\mathrm{mm} \mathrm{h}^{-1}\right]$} & $1.14^{11}$ & $0.25 \pm 0.01$ \\
$K_{a}(316$ stainless-steel) & {$\left[\mathrm{mm} \mathrm{h}^{-1}\right]$} & $1.84 \pm 0.22$ & $0.30 \pm 0.03$ \\
$(1-\alpha)$ (glass) & {$[-]$} & $0.62 \pm 0.18^{11}$ & $0.41 \pm 0.25$ \\
$(1-\alpha)(316$ stainless-steel) & {$[-]$} & $0.30 \pm 0.02$ & $0.61 \pm 0.20$ \\
\hline
\end{tabular}




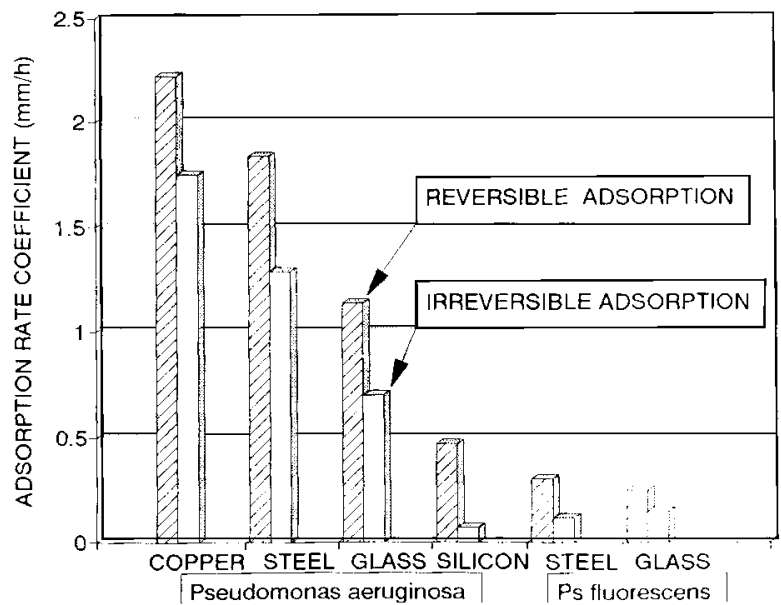

Figure 5. Comparison of reversible and irreversible adsorption coefficient of PS. aeruginosa on copper, silicon, 316 stainless-steel and glass ${ }^{11}$ and Ps. fluorescens on 316 stainless-steel and glass. Shear stress $0.75 \mathrm{~N} \mathrm{~m}^{-2}$.

roughness, however, exerted a large influence on adsorption and desorption. The data also suggest that roughness, $100 \times$ smaller than a microbial cell, influences adsorption. Hence, mechanisms of adsorption (polymer binding, fimbriae adsorption, hydrophobic interactions, etc. $)^{16}$ are related to very small irregularities on a surface. Thus, microbial adhesion may well be influenced by changing the surface topography of the substratum through coatings of organic substrates or polymers. Depending on the original surface topography, coatings can enhance or inhibit microbial adhesion by increasing or decreasing roughness (e.g., SFE) on the substratum. $16,18,32,34$

There was no cell replication of PS. aeruginosa on copper during initial colonization (Fig. 2), which indicates that the adsorbed cells were metabolically inactive, or severely inhibited. With sufficient exposure time, a cell monlayer accumulated on the copper substratum by adsorption processes, and replication of cells in the upper bacteria layers was observed. The increased distance of the cells from the copper surface and, consequently, a lower concentration of inhibitory copper species in the cell microenvironment (concentration gradient) may have reduced the inhibitory effect. For example, reduced toxicity and concentration of copper ions could result from copper complexation or immobilization by the extracellular polymer in the biofilm. In any case, biofilms provided protection for the cells from the toxic effects of copper.

The specific growth rate was found to be significantly lower for cells adsorbed to the silicon or stainless-steel surface than for cells adsorbed to glass at the same bulk water substrate concentration. The generation time was 2.1 hours $\left(\mu_{s}=0.33 \pm 0.06 \mathrm{~h}^{-1}\right)$ on the stainless-steel surface and 2.5 hours $\left(\mu_{s}=0.28 \pm 0.08 \mathrm{~h}^{-1}\right)$ on silicon, which does not represent a significant difference between silicon and stainless-steel. Escher and Charack lis ${ }^{10}$ found a generation time for Ps. aeruginosa on a smooth glass substratum of 1.36 hours $\left(\mu_{s}=0.51 \pm 0.11 \mathrm{~h}^{-1}\right)$. The specific growth rates on all investigated surfaces except copper were found to be higher than the growth rate in the chemostat $\left(\mu=0.2 \mathrm{~h}^{-1}\right)$, but lower than the maximum growth rate of Ps. aeruginosa $\mu_{\max }\left(25^{\circ} \mathrm{C}\right)=$ $0.37 \mathrm{~h}^{-1} .{ }^{9} \mu_{s}$ is smaller than $\boldsymbol{\mu}_{\max }$ for plank tonic cells due to the lower temperature at the solid-water interface $\left(22 \pm 1^{\circ} \mathrm{C}\right)$.

\section{Comparison of Ps. aeruginosa and Ps. fluorescens}

On both tested substrata, adsorption was approximately 5 times slower for Ps. fluorescens than for Ps. aeruginosa. Cellular accumulation of Ps. fluorescens was a much slower process than for Ps. aeruginosa.

Using the BATH assay, the tested Ps. aeruginosa strain was significantly more hydrophobic than the $P$. fluorescens strain. Thus, the more hydrophobic cells accumulated faster. Vanhaecke et al. ${ }^{32}$ measured cell surface hydrophobicity and rate of accumulation of $15 P S$. aeruginosa strains on stainless-steel in a stagnant system, and found a weak positive correlation between adsorption rate and cell surface hydrophobicity.

\section{Simulation of Cell Accumulation}

Cellular colonization on 316 stainless-steel, copper, and silicon were simulated [equation (7)] using the rate coefficients for Ps. aeruginosa and Ps. fluorescens. The effects of substrate concentration on growth rate at the substratum was calculated for low nutrient conditions by using the Monod equation.

Substrata and Bulk Water Nutrient Concentration. Predicted cell accumulation of Ps. aeruginosa is presented for three substrata in Figure 6. Cell concentration was assumed constant at $2 \times 10^{6}$ cell $\mathrm{mL}^{-1}$ in the bulk water, and nutrient was not limiting so the adsorbed bacteria grew at their maximum rate $\boldsymbol{\mu}_{s}$ on each surface (Table II). The total area covered on the silicon substratum was less than $1 \%$ after 700 minutes, on copper $3.4 \%$, and on 316 stainless-steel 16\% (Fig. 6a). A similar simulation of Ps. aeruginosa accumulation on 316 stainlesssteel, copper and silicon was performed for a low nutrient environment ( $0.6 \mathrm{ppm} \mathrm{C}$ ) (Fig. 6b). The total coverage on the silicon surface was still approximately $1 \%$, while accumulation on copper did not change, because there was no growth on the copper surface. Coverage on the stainless-steel surface decreased to $5 \%$ as a result of slower growth rate.

Mixed Population. Cell accumulation was simulated for a mixed population of Ps. aeruginosa and Ps. fluorescens (Fig. 7). Due to a lower adsorption rate, the $P$ s. fluorescens strain accumulates much more slowly than Ps. aeruginosa on the stainless-steel surface even for long exposure times. The surface is totally covered by cells after 950 minutes with $P$ s. fluorescens cells occupying only $6 \%$ of the total surface area. Hence, in 


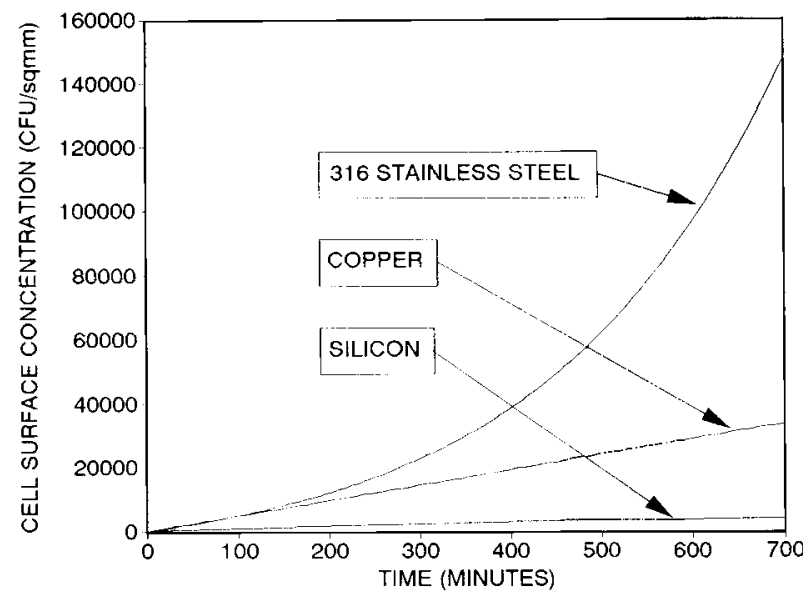

(a)



(b)

Figure 6. Simulation of cell accumulation of Ps. aeruginosa on 316 stainless-steel, copper, and silicon; bulk water cell concentration $2 \times 10^{6}$ cells $\mathrm{mL}^{-1}$, shear stress $0.75 \mathrm{~N} \mathrm{~m}^{-2}$. (a) Rich nutrient conditions in the bulk water ( $\mathrm{S}>10 \mathrm{ppm} \mathrm{C}$ ) and (b) low nutrient conditions in the bulk water $(S=0.6 \mathrm{ppm} C)$ were simulated. Shear stress $0.75 \mathrm{~N} \mathrm{~m}^{-2}$.

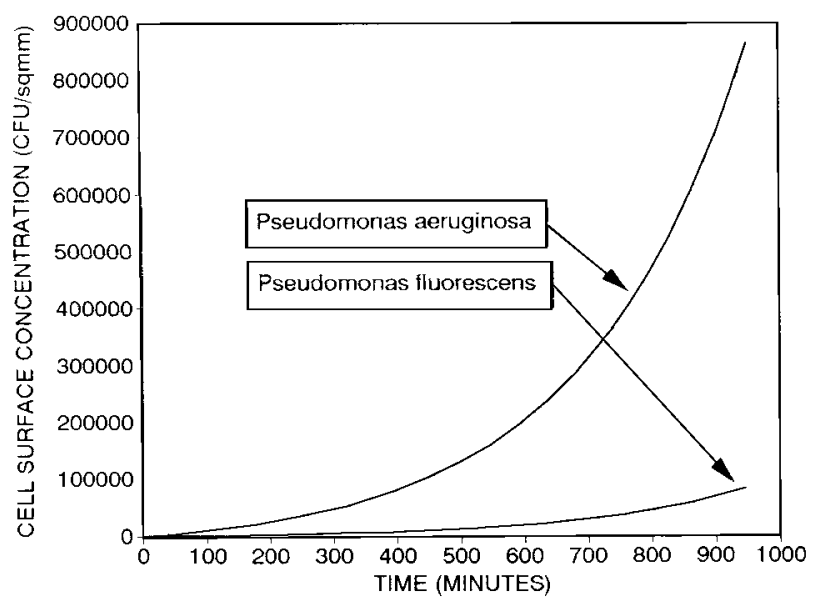

Figure 7. Simulation of cell accumulation of a mixed population of Ps. aeruginosa, Ps. fluorescens on 316 stainless-steel. Cell concentration $4 \times 10^{6}$ cells $\mathrm{mL}^{-1}$ for each species, shear stress $0.75 \mathrm{~N} \mathrm{~m}^{-2}$. mixed populations, faster adsorbing cells are hypothesized to dominate early surface colonization. The difference in adsorption rate of different bacterial species has been used to control composition of mixed microbial populations..$^{23,24}$

\section{CONCLUSIONS}

A technique has been developed to measure initial cell colonization on reflective metal surfaces based on previous work for transparent surfaces. ${ }^{10}$ Experiments were conducted on copper, silicon, 316 stainless-steel, and glass. Ps. aeruginosa and Ps. fluorescens were the test organisms.

1. Image analysis can be used to measure early surface colonization by bacteria cells on reflective surfaces in situ and in real time.

2. During the colonization period, bacterial growth on surface depends on the nutrient supplied by the bulk water as well as properties of the substratum. For example growth was initially inhibited on copper surfaces, but was observed to occur once an intervening layer of cells had formed.

3. Substratum SFE and surface roughness correlate positively with the rate of sorption-related processes.

4. For the 2 bacterial species evaluated, the rate of sorption-related processes depends on the bacterial species and the cell surface hydrophobicity. Ps. fluorescens, with a low hydrocarbon paritioning value, adsorbed at a rate 5 times slower than Ps. aeruginosa, with a high hydrocarbon partitioning value.

Kay Smith is acknowledged for her early work in developing this technique on reflective surfaces. Toomay, Mathis, Associates Technologies, Inc., Bozeman, Montana, graciously provided measurements on RMS roughness. The assistance of Dr. Anne Meyer of the University of Buffalo Industry/ University Cooperative Research Center for Biosurfaces, in measuring surface free energies and surface tensions is also gratefully acknowledged. Dr. Doug Caldwell and associates at the University of Saskatoon, Saskatchewan, Canada are thanked for their contribution of the Pseudomonas fluorescens strains. The authors acknowledge the support of the Office of Naval Research, the National Science Foundation, and the Industrial Associates of the Center.

\section{References}

1. Abbott, A., Rutter, P. R., Berkeley, A.C.W. 1983. The influence of ionic strength, $\mathrm{pH}$, and a protein layer on the interaction between Streptococcus mutans and glass surfaces. J. General Microbiol. 129: 439-445.

2. Adamson, A.W. 1960. Physical chemistry of surfaces. Interscience, New York.

3. Baier, R. E., Meyer, A.E. 1986. Surface analysis. pp. 97-108. In: A. F. von Recum (ed.), Handbook of biomaterials evaluation. Macmillan, New York.

4. Bakke, R., Trulear, M. G., Robinson, J. A., Characklis, W. G. 1984. Activity of Pseudomonas aeruginosa in biofilms: Steady state. Biotechnol. Bioeng. 26: 1418-1424. 
5. Bikerman, J. J. 1970. Physical surfaces. Academic Press, New York.

6. Bowen, B. D., Levine, S., Epstein, N. 1976. Fine particle deposition in laminar flow through parallel-plate and cylindrical channels. J. Colloid Interface Sci. 54: 375-390.

7. Brock, T. D., Madigen, M.T. 1988. Biology of microorganisms. 5th edition. Prentice-Hall, Englewood Cliffs, NJ.

8. Characklis, W. G., Marshall, K. C. 1990. Biofilms: A basis for an interdisciplinary approach, pp. 3-15. In: W. G. Characklis and K.C. Marshall (eds.), Biofilms. Wiley, New York.

9. Characklis, W. G., Marshall, K. C., McFeters, G. A. 1990. The microbial cell, pp. 131-160. In: W. G. Characklis and K.C. Marshall (eds.), Biofilms. Wiley, New York.

10. Escher, A. R., Characklis, W. G., 1990. Modeling the initial events in biofilm accumulation, pp. 445-486. In: W. G. Characklis and K.C. Marshall (eds.), Biofilms. Wiley, New York.

11. Escher, A. R. 1986. Colonization of a smooth surface by Pseudomonas aeruginosa: Image analysis methods. Ph.D. thesis, Montana State University, Bozeman, MT, USA.

12. Fletcher, M. 1980. Adherence of marine micro-organisms to smooth surfaces, pp. 347-374. In: Beachey (ed.), Bacterial adherence (receptors and recognition), vol. 6. Chapman and Hall, London.

13. Hobbie, J. E., Daley, R. J., Jasper, S. 1977. Use of nucleopore filters for counting bacteria by fluorescence microscopy. Appl. Environ. Microbiol. 33: 1225-1228.

14. Kaelble, D. H. 1970. Dispersion-polar surface tension properties of organic solids. J. Adhesion 2: 66-81.

15. Kefford, B., Marshall, K.C. 1984. Adhesion of Leptospira at solid-liquid interface: A model. Arch. Microbiol. 138: 84-88.

16. Kjelleberg, S. 1984. Adhesion to inanimate surfaces, pp. 51-70. In: K.C. Marshall (ed.), Microbial adhesion and aggregation. Springer-Verlag, Berlin.

17. Korber, D. R., Lawrence, J. R., Sutton, B., Caldwell, D. E. 1989. Effect of laminar flow velocity on the kinetics of surface recolonization by mot + and mot-Pseudomonas fluorescens, pp. 1-19. Microbial ecology. Springer-Verlag, New York.

18. Marshall, K.C. 1972. Proceedings of the 3rd International Congress on Marine Corrosion and Fouling, pp. 625-632. Northwestern University Press, Evanston, IL.

19. Marshall, K.C. 1980. Microorganisms and interfaces. BioScience 30: 246-249.

20. Paul, J. H., Jeffrey, W. H. 1985. Evidence for separate adhesion mechanisms of hydrophilic and hydrophobic surfaces in Vibrio proteolyica. Appl. Environ. Microbiol. 50: 431-437.
21. Powell, M. S., Slater, N. K. H. 1983. The deposition of bacterial cells from laminar flows onto solid surfaces. Biotechnol. Bioeng. 26: 891-900.

22. Robinson, J. A., Trulear, M. G., Characklis, W. G. 1984. Cellular reproduction and extracellular polymer formation by Pseudo. monas aeruginosa in biofilms: Steady state. Biotechnol. Bioeng. 26: $1418-1424$.

23. Roos, J.W., Hjortso, M.A. 1989. Control of mixed microbial cultures via specific cell adhesion. Biotechnol. Bioeng. 33: 638-649.

24. Roos, J.W., Hjortso, M. A. 1989. Determination of population balances in a mixed culture by specific cell adhesion. Biotechnol. Techniques 3: 7-12.

25. Rosenberg, M., Gutnick, D., Rosenberg, E. 1980. Adherence of bacteria to hydrocarbons: A simple method for measuring cell surface hydrophobicity. FEMS Microbiol. Lett. 9: 29-33.

26. Rosenberg, M. 1984. Bacterial adherence to hydrocarbons: A useful technique for studying cell surface hydrophobicity. FEMS Microbiol. Lett. 22: 289-295.

27. Stanley, P. M. 1983. Factors affecting the irreversible attachment of Pseudomonas aeruginosa to stainless steel. Can. J. Microbiol. 29: 1493-1499.

28. Stover, J. C., Serati, S. A. 1984. Calculation of surface statistics from light scatter. Optical Eng. 23: 406-412.

29. Trulear, M.G., Characklis, W. G. 1982. Dynamics of biofilm processes. J. Water Pollut. Control Fed. 54: 1288-1310.

30. Turakhia, M., Cooksey, K. E., Characklis, W. G. 1983. Influence of a calcium-specific chelant on biofilm removal. Appl. Environ. Microbiol. 46: 1236-1238.

31. Vanhaecke, E., Pijck, J. 1988. Bioluminescence assay for measuring the number of bacteria adhering to the hydrocarbon phase in the BATH test. Appl. Environ. Microbiol. 54: 14361439.

32. Vanhaeke, E., Remon, J. P., Moors, M., Raes, F., De Rudder, D., Van Petighem, A. 1990. Kinetics of Pseudomonas aeruginosa adhesion to 304 and 316-L stainless steel: Role of cell surface hydrophobicity. Appl. Environ. Microbiol. 56: 788-795.

33. Wanner, O., Gujer, W. 1986. A multispecies biofilm model. Biotechnol. Bioeng. 28: 314-328.

34. Whitekettle, W. K. 1991. Effects of surface-active chemicals on microbial adhesion. J. Indust. Microbiol. 7: 105-116.

35. Zisman, W. A. 1964. Contact angle, wettability, and adhesion, pp. 1-51. In: Advances in chemistry, vol. 43. American Chemical Society, Washington, DC. 